IJMS 2018 vol. 5 (1): 18 - 26

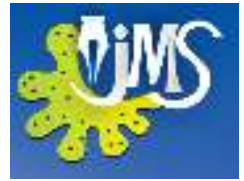

\title{
Detection of Ralstonia solanacearum in Asymptomatic Imported Seed Potato using a DNA-based Method
}

\author{
Perera $\mathrm{AAU}^{1}$, Weerasena OVDSJ ${ }^{1}$, Dasanayaka $\mathrm{PN}^{2}$ and Subhashini MHAD ${ }^{3}$ \\ ${ }^{1}$ Institute of Biochemistry, Molecular Biology and Biotechnology, University of Colombo, Sri Lanka ${ }^{2}$ \\ Department of Botany, Faculty of Applied Sciences, University of Sri Jayewardenepura, Sri Lanka \\ ${ }^{3}$ National Plant Quarantine Service, Katunayake, Sri Lanka
}

\begin{abstract}
Potato is an economically important crop among vegetables grown in Sri Lanka that mainly relies on healthy seed potatoes. About $40 \%$ of the annual seed potato requirement is fulfilled by the import of seed potatoes from Netherland, USA, Germany and France. Import of seed potatoes makes possibilities to enter plant pathogenic pests and diseases to Sri Lanka. Bacterial wilt is one of the most destructive diseases of potato. Ralstonia solanacearum, which causes bacterial wilt of potato, is considered as an important quarantine significant plant pathogen in Sri Lanka. The currently available conventional methods such as culture methods, biochemical methods are time consuming, very laborious and not sensitive for the detection of $R$. solanacearum in imported seed potatoes. Although immunodiagnostic methods are rapid, the sensitivity is not enough to detect the bacterium in asymptomatic or latently infected seed potatoes. In this study, a DNA-based detection method was applied to screen seed potatoes imported into Sri Lanka and 5 out of 30 tested samples (17\%) were positive for $R$. solanacearum. The seed potato samples detected as infected with $R$. solanacearum were further studied and it revealed that the Asian phylotype I and the American phylotype II were detected from seed potato samples imported to the country. Phylotype II (Race 3/biovar 2) was detected in seed potatoes imported from USA and France and both phylotype I and phylotype II (Race 3/biovar 2) were detected in seed potatoes imported from Netherland from where majority of seed potatoes are imported into the country. The quarantine measures should be strictly followed to avoid the spread and establishment of phylotype II, Race 3/biovar 2 strains within the country, as it is the extremely destructive potato pathogen which have a restricted distribution in higher elevations of Sri Lanka. Further, the DNA-based method can be used to identify the pathogen to avoid the introduction or entry of R. solanacearum into the country for the betterment of potato cultivation in Sri Lanka.
\end{abstract}

KEYWORDS: Seed potato, Bacterial wilt, Ralstonia solanacearum, Quarantine pest, Rsol_fliC

Corresponding Author: P.N. Dasanayaka, Email: nilanthiedas@gmail.com 
Detection of Ralstonia solanacearum in Asymptomatic Imported Seed Potato using a DNA-based Method

\section{INTRODUCTION}

Bacterial wilt of potato is considered as one of the most destructive diseases of potato. Ralstonia solanacearum (E. F. Smith), the causal organism of the disease, is considered as a quarantine pest in Sri Lanka. The use of healthy seed potato is the most effective means to control the disease. Therefore, there is a requirement to detect $R$. solanacearum in imported seed potatoes quickly and reliably for quarantine purposes at the port of entry. Consequently this study was aimed to detect $R$. solanacearum in imported seed potato consignments and further characterize using a DNA-based detection method.

\section{BACKGROUND}

Potato (Solanum tuberosum L.) is the world's fourth-largest food crop, as it is an important staple food in the world after maize, wheat and rice (FAOSTAT, 2014). In Sri Lanka also, potato is considered as an economically important vegetable crop. Bacterial wilt caused by $R$. solanacearum is a major problem confronted by the potato farmers in Sri Lanka. It was recorded $5 \%$ to $25 \%$ loss of potato yield in Sri Lanka due to bacterial wilt (Kelaniyangoda et al, 1995). According to the Plant Protection Act No. 35 (Ministry of Agriculture, 1999), $R$. solanacearum is considered as a quarantine pest in Sri Lanka, since some of the strains of this species have not yet been reported, the existing strains also have a restricted distribution (Bandara, 1983; Kelaniyangoda, 1995) and the disease is officially controlled in the country. Introduction of the unavailable strains of $R$. solanacearum into the country may cause major outbreaks of diseases not only in potato but also in other crops in family Solanaceae and Musaceae, causing huge economic losses.
Potato is grown through vegetative propagation using potato tubers, which is also known as seed potato. Use of healthy seed potatoes is one of the most effective means to control bacterial wilt disease in potato (Hayward, 1991). Out of the annual total seed potato requirement, about $5 \%$ is produced by the Department of Agriculture; $55 \%$ is fulfilled by farmers' previous harvest; and the balance of $40 \%$ is imported by the private sector (Kelaniyangoda et al, 2004; Malathy et al, 2005; Nugaliyadde et al, 2005). Seed potato consignments imported to Sri Lanka are inspected visually for pests and diseases at the port of entry. But the visual observation does not give a clear idea about the level of disease infection correctly. Therefore, planting of asymptomatic or latently infected tubers could lead to outbreaks of diseases at the field. Therefore, quarantine restrictions are imposed on import of seed potato, considering the danger of introducing certain pests and pathogens into the country (De Silva and Weerasinghe, 2000; Rajapakse et al, 2006).

The available conventional methods such as culture methods, biochemical assays, pathogenicity test, and biovar determination test are time consuming, labour intensive and not sensitive for the detection of $R$. solanacearum in asymptomatic potato tubers (Champoiseau et al, 2009; van Elsas et al, 2001; Priou et al, 2014). Immunodiagnostic methods such as enzyme - linked immunosorbent assay (ELISA) kits or commercially available immunestrips are used for rapid detection of $R$. solanacearum, but it cannot be used to identify sub-specific strains of $R$. solanacearum including races, biovars and phylotypes. Additionally, immunodiagnostic methods are not much sensitive to detect $R$. solanacearum in asymptomatic potato tubers (Elphinstone et al, 1996; Pradhanang et al, 


\section{A.A.U. Perera, O.V.D.S. Weerasena, P.N. Dasanayaka \& M.H.A.D. Subhashini}

2000) and sometimes give false positive results (Wullings et al, 1998; Llop et al, 1999). Polymerase chain reaction (PCR)-mediated DNA-based techniques are rapid, more sensitive and specific compared to immunodiagnostic methods and can be used for detection of ultralow population of $R$. solanacearum in asymptomatic or latently infected potato tubers. Sensitivity has been reached to $10^{2}-10^{1} \mathrm{cfu} / \mathrm{mL}$ (Llop et al, 1999; Ozakman and Schaad, 2003). The higher sensitivity of the PCR detection may be due to the amplification of living and dead cells or cells at viable - but - not - culturable (VBNC) state (Josephson et al, 1993).

\section{MATERIALS AND METHOD}

Thirty seed potato samples were selected randomly from National Plant Quarantine Service (NPQS), Katunayake that were imported in 2015/2016 and 2016/2017 seasons. Ten tubers from each sample were collected for this study.

Tubers were washed under running tap water and air dried. The skin of potato tubers was removed at the heel end and eyes. Five cylindrical slices of potato tuber core tissue of 1 $\mathrm{cm}$ diameter and approximately $2 \mathrm{~mm}$ thickness were taken at the heel end and at 4 points of eyes using a cork borer. Potato tuber slices were surface sterilized by immersing in 10\% Clorox for $2 \mathrm{~min}$, rinsed thrice with sterile distilled water and blotted dry using sterile filter papers.

Five surface sterilized potato tuber slices $(\sim 0.5$ g) from each tuber were cut into small pieces using a sterile scalpel and transferred into 1.5 $\mathrm{mL}$ microcentrifuge tubes. Blunt-ended micropipette tips $(1000 \mu \mathrm{L}$ tip) were used to crush potato tuber pieces in the tubes. Lysis buffer (567 $\mu \mathrm{L}$ TE buffer ( $\mathrm{pH} 8.0), 30 \mu \mathrm{L} 10 \%$ SDS and $3 \mu \mathrm{L} 20 \mathrm{mg} / \mathrm{mL}$ Proteinase $\mathrm{K}$ ) was added, mixed by vortexing and incubated at 37 ${ }^{\circ} \mathrm{C}$ for $15 \mathrm{~min}$. Thereafter, $100 \mu \mathrm{L}$ of $5 \mathrm{M} \mathrm{NaCl}$ was added, mixed thoroughly and incubated at $65{ }^{\circ} \mathrm{C}$ for $5 \mathrm{~min}$. Then $80 \mu \mathrm{L}$ of pre-heated CTAB $/ \mathrm{NaCl}(10 \% \mathrm{CTAB}$ in $0.7 \mathrm{M} \mathrm{NaCl})$ solution was added and incubated at $65{ }^{\circ} \mathrm{C}$ for another $10 \mathrm{~min}$. Subsequently, $6 \mu \mathrm{L}$ of 10 $\mathrm{mg} / \mathrm{mL}$ RNase A was added and incubated at 37 ${ }^{\circ} \mathrm{C}$ for $15 \mathrm{~min}$. Then the tubes were cooled to room temperature for $5 \mathrm{~min}, 200 \mu \mathrm{L}$ of potassium acetate $(60 \mathrm{~mL} 5 \mathrm{M}$ Potassium acetate, $11.5 \mathrm{~mL}$ glacial acetic acid and distilled water up to $100 \mathrm{~mL}$ ) solution was added, mixed thoroughly by inverting the tubes for $5 \mathrm{~min}$ and centrifuged at $13500 \mathrm{rpm}$ for $10 \mathrm{~min}$. The supernatant of each sample was transferred into fresh $1.5 \mathrm{~mL}$ micro-centrifuge tubes, $600 \mu \mathrm{L}$ of isopropanol was added and centrifuged at 13500 rpm for $5 \mathrm{~min}$. The supernatant of each sample was decanted carefully by leaving the DNA pellet at bottom of the tubes. The pellet was washed with $600 \mu \mathrm{L}$ of $70 \%$ ethanol and tubes were centrifuged at $13500 \mathrm{rpm}$ for $1 \mathrm{~min}$. The supernatant was decanted and the pellet was airdried for 15 min. Finally, the pellet of each sample was dissolved in $50 \mu \mathrm{L}$ of TE buffer $(\mathrm{pH}$ 8.0) and DNA samples were stored at $-20^{\circ} \mathrm{C}$.

R. solanacearum-specific primers, Rsol_fliC (Schonfeld et al, 2003), were used to amplify $400 \mathrm{bp}$ amplicon from the fliC gene, coding for the flagella subunit protein flagellin. PCR was performed in $25 \mu \mathrm{L}$ reaction mixtures, containing $1 \times \mathrm{PCR}$ buffer, $3.5 \mathrm{mM} \mathrm{MgCl}_{2}, 0.2$ $\mathrm{mM}$ dNTP mix, $0.1 \mu \mathrm{M}$ of each primer and $2 \mathrm{U}$ of Taq DNA polymerase (Promega, USA) per reaction with 5 ng of DNA. Amplification was carried out in the thermal cycler (Veriti, Applied Biosystems, USA) programmed as the initial denaturation at $94{ }^{\circ} \mathrm{C}$ for $5 \mathrm{~min}$, followed 
by 35 cycles of denaturation at $94{ }^{\circ} \mathrm{C}$ for $30 \mathrm{~s}$, annealing at $65^{\circ} \mathrm{C}$ for $2 \mathrm{~min}$, extension at $72^{\circ} \mathrm{C}$ for 1 min with a final extension of $72^{\circ} \mathrm{C}$ for 10 min. PCR products were subjected to electrophoresis in $1 \%(\mathrm{w} / \mathrm{v})$ agarose gel containing $0.5 \mu \mathrm{g} / \mathrm{mL}$ ethidium bromide, at a constant voltage of $50 \mathrm{~V}$ for $90 \mathrm{~min}$ and visualized under UV light using the gel documentation system (Quantum ST4 1100/ 20M, Vilber Lourmat, France).

Genomic DNA extracted from imported seed potato samples, detected as positive for $R$. solanacearum were subjected to phylotype specific multiplex-PCR (Pmx-PCR) to identify phylotype of $R$. solanacearum using $R$. solanacearum species-specific primers, 759/760 (Opina et al, 1997) in combination with phylotype-specific primers (Fegan and Prior, 2005). Pmx-PCR was performed in $25 \mu \mathrm{L}$ reaction mixtures, containing $1 \times \mathrm{PCR}$ buffer, 2.0 $\mathrm{mM} \mathrm{MgCl} 2,0.2 \mathrm{mM}$ dNTP mix, $1 \times$ primer mix and $1 \mathrm{U}$ of Taq DNA polymerase per reaction with 40 ng of DNA. Amplification was carried out in the thermal cycler programmed as the initial denaturation at $96{ }^{\circ} \mathrm{C}$ for $5 \mathrm{~min}$, followed by 30 cycles of denaturation at $94{ }^{\circ} \mathrm{C}$ for $30 \mathrm{~s}$, annealing at $59{ }^{\circ} \mathrm{C}$ for $90 \mathrm{~s}$, extension at $72{ }^{\circ} \mathrm{C}$ for $90 \mathrm{~s}$ with a final extension of $72{ }^{\circ} \mathrm{C}$ for 20 min. The PCR products were subjected to electrophoresis in $2 \%(\mathrm{w} / \mathrm{v})$ agarose gel and visualized using the gel documentation system. Genomic DNA extracted from imported seed potato samples, detected as $R$. solanacearum phylotype II were further subjected to PCR using Race 3/biovar 2 (R3bv2)-specific primers, 630 and 631 (Fegan et al, 1998), to distinguish strains pathogenic to potato from other strains classified under phylotype II. PCR was performed in $25 \mu \mathrm{L}$ reaction mixtures, containing $1 \times$ PCR buffer, $2.5 \mathrm{mM} \mathrm{MgCl} 2,0.2$ $\mathrm{mM}$ dNTP mix, $0.2 \mu \mathrm{M}$ of each primer and $1 \mathrm{U}$ of Taq DNA polymerase per reaction with 20 ng of DNA. The PCR products were subjected to electrophoresis in $1 \%(\mathrm{w} / \mathrm{v})$ agarose gel and visualized using the gel documentation system.

\section{RESULTS \& DISCUSSION}

In the present study, the DNA-based detection method was applied to screen imported seed potato to get an idea about the probability of entrance of $R$. solanacearum into Sri Lanka through seed potatoes. Out of 30 imported seed potato samples tested by the method 5 samples were detected as infected with $R$. solanacearum. Two tested seed potato samples imported in 2015/2016 season (variety Laperla and Granola imported from Netherland); and three tested samples imported in 2016/2017 season (variety Red La Soda imported from USA, Granola from Netherland, and Sassy from France) were found to be infected by the bacterium. The level of infection of 3 tested seed potato samples was below the tolerance level. The level of infection of 2 tested seed potato samples was beyond the tolerance level of $<40 \%$ (Table 1 ). According to the results of the study, there was $17 \%$ probability of detection of $R$. solanacearum infected seed potatoes from imported consignments which were used for potato cultivation in the country. It revealed that the pathogen can enter into the new fields via latently infected imported seed potatoes, then can disseminate to other potato-growing fields and establish in the country. As the pathogen has a restricted distribution in Sri Lanka presently, this process should be avoided.

Genomic DNA extracted from those 5 imported seed potato samples, detected as infected with $R$. solanacearum, were further subjected to Pmx-PCR to identify phylotype (Figure 1). The 


\section{A.A.U. Perera, O.V.D.S. Weerasena, P.N. Dasanayaka \& M.H.A.D. Subhashini}

result showed that two out of four phylotypes of $R$. solanacearum: the Asian phylotype I and the American phylotype II were detected from imported seed potato samples. Out of 5 samples tested 4 samples produced 280 bp and 372 bp amplicons, confirming the infection as $R$. solanacearum phylotype II. One tested imported seed potato sample produced $280 \mathrm{bp}$ and 144 bp amplicons in Pmx-PCR. It was confirmed that the sample was infected with $R$. solanacearum phylotype I (Table 1). Phylotype I was detected from $20 \%$ and phylotype II was detected from $80 \%$ of imported seed potato samples which were infected from $R$. solanacearum. Both phylotype I and phylotype II were detected in seed potatoes imported from Netherland from where majority of seed potatoes are imported into Sri Lanka. This will lead to major outbreaks of bacterial wilt disease in the country.

Genomic DNA extracted from imported seed potato samples, identified as phylotype II were further subjected to PCR with R3bv2-specific primers and the PCR confirmed that all phylotype II as R3bv2, producing 307 bp amplicon (Table 1).

$R$. solanacearum phylotype II, R3bv2 has a worldwide distribution and is pathogenic to potato with high virulence (Buddenhagen et al, 1962). However, this strain has a restricted distribution in Badulla and Nuwara Eliya of Sri Lanka (Bandara, 1983; Kelaniyangoda, 1995). Therefore, quarantine measures should be advocated to avoid the entrance of these $R$. solanacearum strains into Sri Lanka via imported seed potato

\section{Table 1. Imported seed potato samples detected as infected with Ralstonia solanacearum}

\begin{tabular}{lllccc}
\hline Reference No. & Origin & Variety & $\begin{array}{c}\text { Level of } \\
\text { infection* }\end{array}$ & Phylotype & Race/biovar \\
\hline $21 / 2015 / 2016$ & Netherland & Laperla & $20 \%$ & II & R3bv2 \\
$40 / 2015 / 2016$ & Netherland & Granola & $30 \%$ & II & R3bv2 \\
$05 / 2016 / 2017$ & USA & Red La Soda & $40 \%$ & II & R3bv2 \\
$07 / 2016 / 2017$ & Netherland & Granola & $10 \%$ & I & ND \\
$12 / 2016 / 2017$ & France & Sassy & $40 \%$ & II & R3bv2 \\
\hline
\end{tabular}

*The level of infection was determined as the percentage of number of potato tubers detected as infected with $R$. solanacearum out of ten potato tubers tested for a sample.

Note: The tolerance level of $R$. solanacearum infection for imported seed potato consignments was considered as $<40 \%$ (National Plant Quarantine Service, Katunayake, 2016).

ND: Not determined 


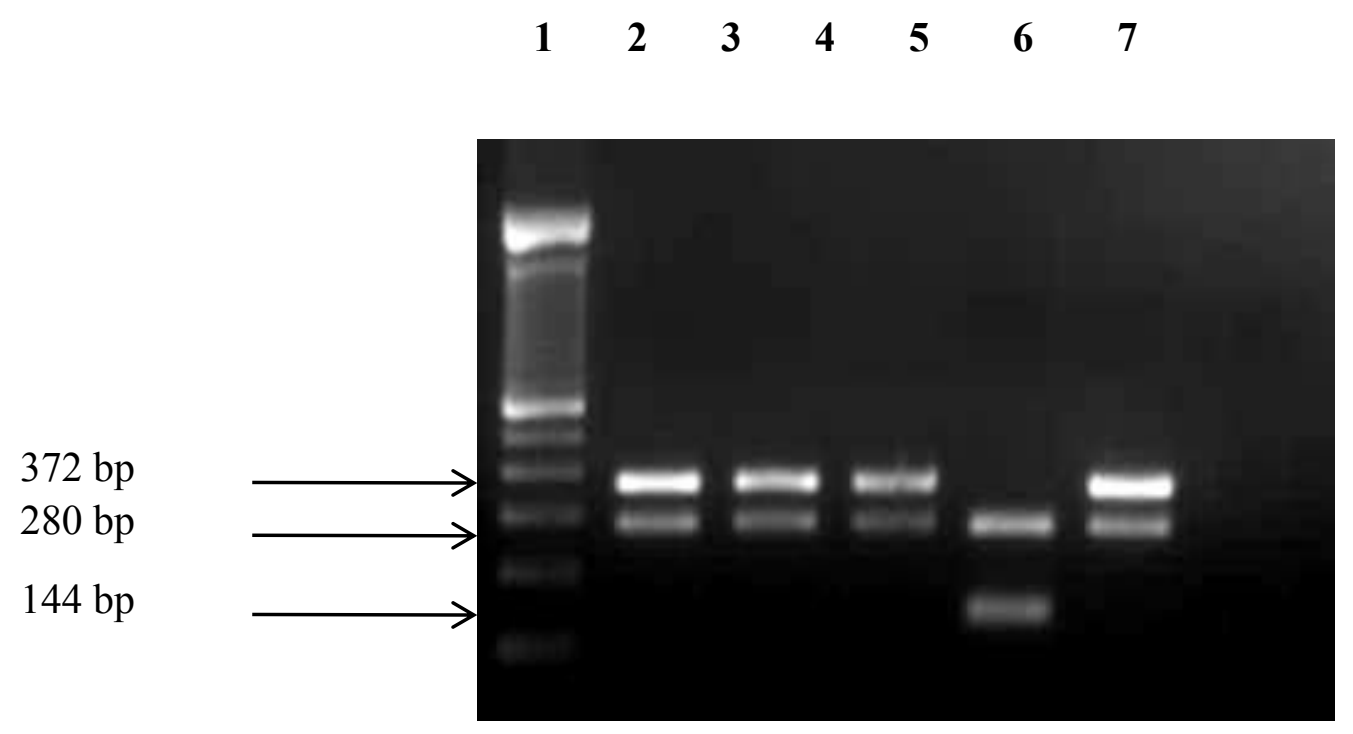

Figure 1. Pmx-PCR products of genomic DNA extracted from imported seed potato samples detected as infected with Ralstonia solanacearum.

Lane 1: 100 bp ladder; Lane 2 to 6: samples of 21/2015/2016 (Laperla from Netherland), 40/2015/2016 (Granola from Netherland), 05/2016/2017 (Red La Soda from USA), 07/2016/2017 (Granola from Netherland) and 12/2016/2017 (Sassy from France), respectively; Lane 7: Negative control. Based on the results, sample of 07/2016/2017 was detected as infected with $R$. solanacearum phylotype I and other 4 samples with $R$. solanacearum phylotype II.

\section{CONCLUSION \& FUTURE WORK}

The DNA-based detection method was able to screen imported seed potato for $R$. solanacearum and it was concluded that there was $17 \%$ probability of detection of $R$. solanacearum infected seed potatoes from imported consignments.

Phylotype study of imported seed potato samples revealed that two phylotypes of $R$. solanacearum: the Asian phylotype I and the American phylotype II were detected from seed potato samples imported to the country. Phylotype II was the major $R$. solanacearum strains entered into Sri Lanka through seed potatoes imported from Netherland, USA and France and phylotype I was detected in seed potatoes imported from Netherland.

The DNA-based detection method can be implemented by NPQS to screen imported seed potatoes to detect and characterize $R$. solanacearum to prevent the entry of strains of the pathogen which have not yet been reported in Sri Lanka. It is very important that the method should be validated before put to use. Further, using these findings, quarantine regulations should be strengthened to secure potato crop in the country. 
A.A.U. Perera, O.V.D.S. Weerasena, P.N. Dasanayaka \& M.H.A.D. Subhashini

\section{ACKNOWLEDGEMENT}

Authors wish to acknowledge the National Research Council of Sri Lanka for the grant provided and Dr. Jayantha Senanayake, Additional Director, NPQS, Katunayake for giving permission to use imported seed potato samples for the study.

\section{REFERENCES}

BANDARA JMRS. Biotype distribution of vascular wilt pathogen Pseudomonas solanacearum in Sri Lanka. Journal of the National Science Council of Sri Lanka. 1983; 11(1):65-76.

BUDDENHAGEN IW, SEQUEIRA L, KELMAN A. Designation of races of Pseudomonas solanacearum. Phytopathology. 1962; 52:726.

CHAMPOISEAU PG, JONES JB, ALLEN C. Ralstonia solanacearum race 3 biovar 2 causes tropical losses and temperate anxieties. Plant Health Progress. 2009; doi:10.1094/PHP-20090313-01-RV.

DE SILVA RSY, WEERASINGHE ASP. Pests detected in agricultural commodities imported to Sri Lanka. Annual Symposium of the Department of Agriculture, Sri Lanka. 2000; 2:65-70.

ELPHINSTONE JG, HENNESSY J, WILSON JK, STEAD DE. Sensitivity of different methods for the detection of Ralstonia solanacearum in potato tuber extracts. Bulletin OEPP/EPPO Bulletin. 1996; 26:663-678.
FAOSTAT. The Potato Sector; 2014. http://www.potatopro.com/world/potatostatistics. Accessed 5 Aug 2016.

FEGAN M, PRIOR P. How complex is the Ralstonia solanacearum species complex?. In: Allen C, Prior P, Hayward AC, editors. Bacterial Wilt Disease and the Ralstonia solanacearum Species Complex. St. Paul, Minnesota: American Phytopathological Society; 2005. p. 449-461.

FEGAN M, TAGHAVI M, SLY LI, HAYWARD AC. Phylogeny, diversity and molecular diagnostics of Ralstonia solanacearum. In: Prior P, Allen C, Elphinstone J, editors. Bacterial Wilt Disease: Molecular and Ecological Aspects. Paris, France: INRA Editions; 1998. p.19-33.

HAYWARD AC. Biology and epidemiology of bacterial wilt caused by Pseudomonas solanacearum. Phytopathology. 1991; 29:65-87. JOSEPHSON KL, GERBA CP, PEPPER IL. Polymerase chain reaction detection of nonviable bacterial pathogens. Applied and Environmental Microbiology. 1993; 59:35133515.

KELANIYANGODA DB, EKANAYAKE HMRK, KEKUNADOLA GDCN, WEERASINGHE UR, SUBHASHINI MHAD. Development of a quick detection technique for identification of Erwinia carotovora carotovora and E. carotovora atroseptica in imported seed potato. Annals of the Sri Lanka Department of Agriculture. 2004; 6:123-129.

KELANIYANGODA DB, THARMARAJAH SK, HERAT LG. Effect of green manure, organic manure and chemicals on the incidence of bacterial wilt (Ralstonia (Pseudomonas) 
Detection of Ralstonia solanacearum in Asymptomatic Imported Seed Potato using a DNA-based Method

solanacearum) in potato. Tropical Agriculturist. 1995; 150:35-47.

KELANIYANGODA DB. Identification of biovars of Ralstonia (Pseudomonas) solanacearum E.F.Smith in the upcountry of Sri Lanka. Tropical Agriculturist. 1995; 150:17-26.

LLOP P, CARUSO P, CUBERO J, MORENTE C, LOPEZ MM. A simple extraction procedure for efficient routine detection of pathogenic bacteria in plant material by polymerase chain reaction. Journal of Microbiological Methods. 1999; 37:23-31.

\section{MALATHY P, ARIYARATNE D,} NUGALIYADDE MM. Variability in physiological, morphological and agronomic characteristics of different propagule types of potato. Annals of the Sri Lanka Department of Agriculture. 2005; 7:165-173.

MINISTRY OF AGRICULTURE. Plant Protection Act, No. 35 of Sri Lanka 1999. Acts and Regulations.

http://extwprlegs1.fao.org/docs/pdf/srl37310.pd f. Accessed 5 Oct 2011.

NUGALIYADDE MM, DE SILVA HDM, PERERA R, ARIYARATNA D, SANGAKKARA UR. An aeroponic system for the production of pre-basic seeds of potato. Annals of the Sri Lanka Department of Agriculture. 2005; 7:199-208.

OPINA $\mathrm{N}$, TAVNER $\mathrm{F}$, HOLLWAY $\mathrm{G}$, WANG JF, LI TH, MAGHIRANG R, et al. A novel method for development of species and strain-specific DNA probes and PCR primers for identifying Burkholderia solanacearum (Formerly Pseudomonas solanacearum). Asia
Pacific Journal of Molecular Biology and Biotechnology. 1997; 5(1):19-30.

OZAKMAN M, SCHAAD NW. A real-time Bio-PCR assay for detection of Ralstonia solanacearum race 3 , biovar 2 , in asymptomatic potato tubers. Canadian Journal of Plant Pathology. 2003; 25:232-239.

PRADHANANG PM, ELPHINSTONE JG, FOX RTV. Sensitive detection of Ralstonia solanacearum in soil: a comparison of different detection techniques. Plant Pathology. 2000; 49:414-422.

PRIOU S, ALEY P, CHUJOY E, LEGAMA B, FRENCH ER. Integrated control of bacterial wilt of potato. CIP. 2014.

http:/cipotato.org/wp-content/uploads/2014/

10/ guiaing.pdf. Accessed 7 Aug 2015.

RAJAPAKSE RGAS, EKANAYAKE R, RANATHUNGA RK, PERERA RNI, WIJESEKARA RDSS, EKNELLIGODA IA, ABEKOON SAMR. Plant pathogens introduced to Sri Lanka through imported seed potato (Solanum tuberosum L.). Annals of Sri Lanka Department of Agriculture. 2006; 8:371-377.

SCHONFELD J, HEUER H, VAN ELSAS JD, SMALLA K. Specific and sensitive detection of Ralstonia solanacearum in soil on the basis of PCR amplification of fliC fragments. Applied and Environmental Microbiology. 2003; 69(12):7248-7256.

VAN ELSAS JD, KASTELEIN P, DE VRIES PM, VAN OVERBEEK LS. Effects of ecological factors on the survival and physiology of Ralstonia solanacearum bv. 2 in irrigation water. Canadian Journal of Microbiology. 2001; 47:842-854. 
A.A.U. Perera, O.V.D.S. Weerasena, P.N. Dasanayaka \& M.H.A.D. Subhashini

WULLINGS BA, VAN BEUNINGEN AR, JANSE JD, AKKERMANS ADL. Detection of Ralstonia solanacearum, which causes brown rot of potato, by fluorescent in situ hybridization with $23 S$ rRNA-targeted probes. Applied and Environmental Microbiology. 1998; 64(11):4546-4554. 